\title{
Perceptions of distance students on the efficacy of Online Public Access Catalogue as an information retrieval tool at the University of Zambia
}

\author{
Pailet Chewe \\ Acting Collection Development Librarian \\ University of Zambia Library \\ pchewe@unza.zm
}

\author{
Eness M. M Chitumbo \\ Serials Librarian \\ University of Zambia Library \\ echitumbo@unza.zm
}

\begin{abstract}
The survey aims to investigate distance students' perceptions of the efficacy of the online catalogue as a tool for information retrieval at the University of Zambia. A survey research design has been adopted in the study. Convenient sampling method was used to select 160 distance students. A structured questionnaire was developed and distributed to undergraduate distance students. The Statistical Package for Social Sciences (SPSS) software was used to analyse quantitative data into frequencies and percentages. The study established majority of distance students rarely used the online public access catalogue in exploiting the resources in the university library. Instead they employed shelf-to-shelf browsing in information searching and retrieval skills. Lack of proper orientation and user education were identified as major factors militating against their maximum utilization and exploitation of the resources in the university library. The findings of the study will inform stakeholders on how best to turn around the negative trends of OPAC.
\end{abstract}

Keywords: OPAC, information retrieval tool, distance students, University of Zambia

\section{INTRODUCTION}

The provision of quality library services to those who learn at a distance is undoubtedly one of the most exciting and challenging developments that have occurred in contemporary librarianship. Distance education has led to the development of specialised library and information services that can appropriately be called distance librarianship. The genesis of distance librarianship is grounded in the creation of the largescaled spread of distance education to satisfy personal and national educational goals. The terms distance learning, distance teaching, open learning or extended degree programme are used interchangeably for distance education. A library is the central organ in a university which plays a significant role in achieving the objectives of higher education

With the rapid development of Information and Communication Technology (ICT) and the ensuing growth of Online Public Access Catalogue (OPAC), access to library resources is provided in a more convenient and easy way. OPAC refers to information retrieval system composed of database of bibliographic records describing the books and other materials owned by a library or library system (Popp, 2012). OPAC is accessible online regardless of geographical location making it convenient for remote users or via work stations usually concentrated near the library reference desk to make it easy for a user to request the assistance of a trained reference librarian.

Nevertheless, the introduction of these emerging technologies into the libraries results in different skills requirements to enhance full utilization of them. Therefore, the success of OPAC implementation in the library depends greatly on the extent to which users are kept well informed about OPAC and are trained to equip them with requisite skills so that they can appreciate and make more effective use of OPAC services. Therefore, optimal use of OPAC can be achieved by welldesigned training programme, effective marketing strategy and improved accessibility to internet connected computers (Msagati, 2014).

This study investigates perception of distance students toward the efficacy of OPAC as an information retrieval tool at UNZA.

\section{A. DISTANCE-LEARNING LIBRARY SERVICES}

The growth of distance learning programmes at the UNZA has tremendous implications for library services because the 
Library is a dynamic partner in distance learning dedicated to the provision of information resources to this group of patrons. The adoption of OPAC in the library is of particular interest for distance learners as they need not to spend time to travel from their location to the library to know the availability of a particular information resource. With OPAC, distance students can now browse online through the remote access service the physical collection of the library anywhere regardless of their geographical location and thus this initiative has saved their time and cost of travelling from their geographical locations.

\section{STATEMENT OF THE PROBLEM}

UNZA Library has heavily invested on the collection development to serve its patrons and implemented OPAC to facilitate easy retrieval of these resources. Given the nature of distance students being dispersed along the length and breadth of the country, the university library has embraced OPAC to overcome challenges associated with distance and remote locations of patrons. Nonetheless, all these efforts will be useless if OPAC remain unused or failed to serve its intended purpose. It is therefore expected that distance students should make effective use of OPAC to facilitate easy retrieve of these materials so as to get value for money. Thus, in view of this, monitoring of usage of OPAC by distance students is necessary to establish whether these efforts are yielding desired fruit. Today, there is scanty research on the perceptions toward OPAC by distance students at UNZA. It is against this background that this study was embarked upon.

\section{B. OBJECTIVES OF THE STUDY}

The purpose of this study was to investigate perceptions of distance students toward the efficacy of OPAC as an information retrieval tool at UNZA. Specific objectives of the study are:

1. To investigate distance students' awareness and use of OPAC

2. To examine challenges faced by distance students when accessing the OPAC

3. To suggest some measures for the improvement of OPAC usage.

\section{CONCEPTUAL FRAMEWORK}

The conceptual framework adopted for this study is the Standards for Distance Learning Library Service developed by ACRL (2008). The framework is a concept which postulates that every higher learning institution must have a library for students, faculty members, staff and administrators of that institution. Students should be able to have the right to use resources and services of the library irrespective of their location. The framework aligns most closely with the purpose of this study as compared to theories in DE. The constructs identified in the Philosophy of the Standards for the framework are as follows: Access, Support and Information literacy and these are relevant to the context of this study.

\section{LITERATURE REVIEW}

Today, most libraries worldwide have made a significant leap in terms of embracing and adopting technologies in order to increase access to and use of library collections. Nonetheless, in spite of such huge investment, it is apparent that awareness and use of OPAC among library users play pivotal role on influencing the effective utilization of the library resources to enhance core business of the university, namely teaching, learning and research among scholars.

A study by Ruzegea (2012) opines that awareness of OPAC is the knowledge of this facility and it is also a first step to increase usage of library educational resources to aid students in their learning process. This is supported by Ebiwolate (2010) found that majority of students were not aware of library catalogue as a result they had never used the catalogue. The study further revealed that, due to limited use of OPAC, majority of students resorted to browse through shelves technique to locate books which resulted in frustration and thus militated against the use of library information resources. Similarly, a study by Bamidele et al. (2014) found that majority of respondents were not aware of the efficacy of OPAC as a retrieval tool for library information resources. Equally, Adedibu (2008) examined catalogue use by science students and showed that the users of the OPAC represented a small portion with 33 respondents.

Studies by (Arshad, 2012 and Asubiojo and Fabunmi, 2013) have identified impediments to effective use of OPAC. These factors are lack of awareness, inadequate IT skills, erratic power supply, network failure, inadequacy of computer terminals and searching library materials in oriental languages such as Urdu, Persian and so forth.

On the other hand, studies have revealed that the use of OPACs has gradually become more important worldwide and many university libraries have embraced OPAC as the potential information retrieval tool. Ansaar and Amita (2008) on the study of awareness and use of the online public access catalogue (OPAC) in five Delhi libraries found that a high percentage of respondents are utilising the OPAC as a search tool for retrieving documents. Also,

Yusuf (2012) on the study to investigate effective use of OPAC at the Lagos State Polytechnic Library, noted that majority of respondents used OPAC to retrieve materials in the library while. Such improvement is partly due to increased awareness campaign, adequate number of access points and proper user education programme to users on the use of catalogue for retrieval of books and other information sources.

\section{RESEARCH METHODOLOGY}

Survey method of research has been employed to conduct the study. A structured questionnaire was designed and pre-tested to collect the data from distance students in April 2017. A five-point Likert type scale with response categories was used to mainly get responses from the subjects of the study. Space was also provided for additional comments and suggestions at the end of the questionnaire. The population for this study consisted of all the 8,500 distance students registered under the Institute of Distance Education at UNZA. A sample size of sixty (60) respondents was purposively selected. The data collected through respondents' survey were analyzed and interpreted using Statistical Package for Social Sciences (SPSS) for Windows version 16.0. 


\section{A. Profile of respondents}

For the purposes of collecting information from distance students, 100 questionnaires were distributed to students that had come for residential school in April, 2017. Out of the 100 questionnaires distributed to the respondents 90 (90\%) copies were duly completed, returned and found valid for analysis. Out of the 90 respondents, $61(67.78 \%)$ were males females and $29(32.22 \%)$ were females. It is clear from the results that more males participated in this study as compared to their female counterparts.

With regard to age distribution, 35 (38.9\%) were aged 20 years and below, $17(18.9 \%)$ were aged between 21 and 30 years, $18(20 \%)$ were between 31 and 40 years, $12(13.3 \%)$ were between 41 and 50 years and $6(6.7 \%)$ were above 50 years.

Further analysis showed that $20(22.22 \%)$ were in the first year, $15(16.67 \%)$ were in second year, $30(33.33 \%)$ were in third year and $25(27.78 \%)$ were in the fourth year.

The following were their programs of study:

Table 1: Programs of study

\begin{tabular}{|l|c|c|}
\hline Academic Programs & Frequency & $\%$ \\
\hline BALIS & 20 & $22.2 \%$ \\
\hline BA & 31 & $34.4 \%$ \\
\hline BAEd & 12 & $13.3 \%$ \\
\hline B Adult Ed & 20 & $22.2 \%$ \\
\hline Master of History & 5 & $5.6 \%)$ \\
\hline BA Dev't Studies & 2 & $2.2 \%$ \\
\hline
\end{tabular}

\section{RESULTS}

Awareness of OPAC by distance students

Respondents were asked to state their level of awareness of OPAC. Results in Table 1 indicate that 78 respondents out of $90(86.67 \%)$ were not aware of OPAC while $12(13.33 \%)$ were aware of OPAC. The findings of this study indicated that majority of respondents had low level of awareness on the OPAC facility.

Table 2: Awareness of OPAC

\begin{tabular}{|l|c|c|}
\hline Awareness & Frequency & $\%$ \\
\hline Yes & 12 & $13.33 \%$ \\
\hline No & 78 & $86.67 \%$ \\
\hline Total & 90 & $100 \%$ \\
\hline
\end{tabular}

\section{A. Level of OPAC use by distance students}

Respondents were asked to indicate their level of use of OPAC. Results in Table 2 show that the majority of respondents $77(85.56 \%)$ did not use OPAC, while few respondents $13(14.44 \%)$ used OPAC to retrieve library materials.
Respondents who indicated to use OPAC were asked to state their frequency of using the OPAC. Figure 1 indicates that 4 respondents out of $13(30.77 \%)$ used OPAC on daily basis, 6 of them $(46.15 \%)$ used OPAC in 2- 3 days a week and $3(3.33 \%)$ used OPAC occasionally. These findings suggest that, the majority of respondents used OPAC to search materials in the library on occasional basis.

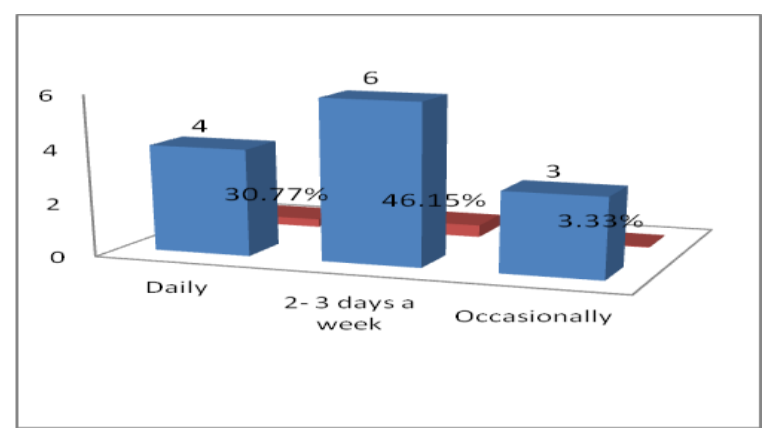

Fig. 1: Frequency of OPAC use

\section{Training on the use of OPAC}

Respondents who indicated to use OPAC were asked to state whether they had attended training on the use of OPAC. Results in Table 3 show that 5 out of 13(38.46\%) attended training on the use of OPAC while $8(61.54 \%)$ did not. It is evident from these findings that majority of respondents did not attend user education training.

Table 3: Training on OPAC use

\begin{tabular}{|l|c|c|}
\hline Training & Frequency & $\%$ \\
\hline Yes & 5 & $38.46 \%$ \\
\hline No & 8 & $61.54 \%$ \\
\hline Total & 13 & $100 \%$ \\
\hline
\end{tabular}

\section{Information retrieval methods}

Respondents were asked to reveal methods which were used to retrieve Library materials. Figure 2 shows that 62 out of 90 $(68.89 \%)$ retrieved information through direct browsing on the shelves, $12(13.33 \%)$ retrieved information with help from colleagues and $9(10.0 \%)$ retrieved information with the assistance of the library staff while $7(7.78 \%)$ did not indicate how they retrieved information resources from the library.. From the analysis of these findings, it is clear that majority of respondents retrieved materials in the library by using browse through shelves technique.

Direct browsing on the shelf $\square$ Colleagues $n$ Librarians

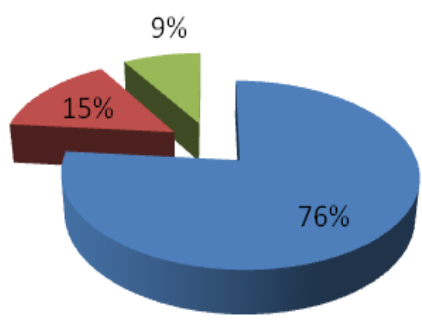

Fig. 2: Information retrieval methods 


\section{E. Challenges of using OPAC}

In order to find out the challenges that users encounter in the course of using the library OPAC to access library resources, respondents who indicated that they had used OPAC were asked to indicate challenges in using OPAC. Findings in Table 4 reveal that 6 out of 13 respondents mentioned limited access to computers, 5 stated inadequate searching skills and 3 mentioned low bandwidth. From these findings, it is clear that limited access to computers is a major challenge facing use of OPAC by distance learners.

Table 4: Challenges

\begin{tabular}{|l|c|c|}
\hline Challenges & Frequency & $\%$ \\
\hline Limited access to computers & 6 & $46.15 \%$ \\
\hline Inadequate searching skills & 5 & $38.46 \%$ \\
\hline Low bandwidth & 3 & $23.08 \%$ \\
\hline Total & 13 & $100 \%$ \\
\hline
\end{tabular}

F. Opinions of respondents on how to enhance OPAC usage by distance students

An open ended question was given to students to know their opinions regarding measures of how OPAC usage can be enhanced. Below are their views:

$\checkmark \quad$ Most of the participants were dissatisfied with the number of OPAC terminals. Users indicated that they wanted terminals at their point of need such as in the stack and in reading areas.

$\checkmark \quad$ Need for proper guidance from the librarians on how to use the OPAC effectively and what OPAC services are offered to students.

$\checkmark \quad$ There is a need to train the users to acquire basic skills in searching. The users suggested be providing with assistance for the use of OPAC, by the library staff and also suggesting for User Orientation Programmes.

$\checkmark$ Some respondents suggested for the distribution of up todate library guides explaining about how to use the OPAC and other library services, by the library staff

\section{Discussions}

The necessity for an effective information retrieval tool in the library cannot be overemphasized. OPAC being the most efficient information retrieval tool is critical in facilitating easy retrieval of library materials. This research attempted to investigate perception of OPAC among distance students at UNZA. Findings reveal that most of respondents were not aware of OPAC and thus only few respondents of them used OPAC to retrieve library materials. These findings conform to the findings of a study by Bamidele et al. (2014) who found that that majority of the respondents were not aware of OPAC. It is evident from these findings that lack of awareness of OPAC has a negative impact on the use of this tool and eventually leads to underutilization of library resources. The findings of this study are consistent with the view of Asemi and Riyahiniya (2007) who opined that when a user is made aware of the resource, it will usually lead to the effective use of that resource. This study is also attested to by Fati and Adetimirin (2015) who found a significant relationship between awareness and utilization of OPAC. On the contrary to these findings, a study by Ruzegea (2012) found that all students (100\%) were aware of OPAC and its functionalities.

This study has also established that study participants used various methods to retrieve information resources in the library. The most commonly used method was through directly browsing the shelves while the least used method was OPAC. The probable reason for its extensive use is because browse through shelves method is the major alternative available at their disposal. This finding confirms the findings of Ebiwolate (2010) who revealed that majority of respondents were not aware of OPAC with the result that majority of students did not use OPAC to retrieve materials in the library. Contrary to these findings, Yusuf (2012) study on the effective use of OPAC to retrieve library education resources revealed that (91.14 percent) of respondents used OPAC to retrieve materials in the library while (8.86 percent) of respondents did not use OPAC to browse the library collection.

Apart from awareness of OPAC, other factors such as training on the use of OPAC also plays crucial role in influencing effective use of this facility. The findings from Table 8 reveals that majority of respondents (78.9 percent) who used OPAC to retrieve library materials were somewhat satisfied with OPAC, while (21.1 percent) of them were satisfied with OPAC. This might be attributed to the fact that a good number of respondents (71.15 percent) from Table 6 did not attend training on the use of OPAC and so the majority of respondents lack requisite searching skills.

These results support the findings of Islam (2010) which revealed that majority of respondents prefer to browse books through shelves because there is no proper user education programme in the university to make proper use of library catalogue. The author suggested on users education programme to facilitate the use of catalogue.

These findings also confirm the findings of Thanuskodi (2012) who found that typical users of OPAC do not have the range of knowledge and skills needed for effective subject search. Thus, user community needs to be oriented and trained on the use of OPAC in order to ensure optimum use of the resource. Such efforts would help to pass on information literacy skills to library users to enable them to make effective use of OPAC. The study further identified other factors that hinder the effective use of OPAC. These factors were low bandwidth, limited access to computer and recurrent power outages. These findings corroborates to previous findings by (Mulla and Chandrashekara, 2009; Fabunmi and Asubiojo, 2013).

Thus, it is clear that in spite of efforts being taken by the library to deploy OPAC to facilitate access and use of library information resources, majority of distance students have not made effective use of the facility to retrieve information resources. Fati and Adetimirin (2015) echoed the same sentiments by stating that setting up OPAC without target users being sensitized about its availability, functions and benefits can be considered as a waste of resources.

\section{Conclusion and recommendations}

The present study investigated perception of OPAC by distance students at UNZA. The findings revealed that the use of OPAC by distance students was extremely. The main reasons for this state of affairs were due to low awareness of OPAC, inadequate searching skills, limited access to computers and low bandwidth. 
These findings suggest that, browse through shelves method was the highly used information retrieval method amongst distance learners probably because it was the major retrieval technique available at their disposal. It is therefore important that the library should help its users to adopt and assimilate OPAC since its effective use has a significant impact on the teaching, learning and research activities. In order to enhance full exploitation of OPAC services amongst distance students, there is need for systematic and periodic user information literacy training for distance students during orientation sessions.

\section{Recommendations}

Based on the findings of this study, the following recommendations are hereby advanced:

1. Distance students should be aware of the benefits of using OPAC as an essential information retrieval tool.

2. Distance students should be encouraged to use the OPAC in exploiting the resources in the university library.

3. Distance students should be discouraged from using shelfto-shelf browsing as their preferred method of searching library materials

4. The respondents should be given proper orientation and user education as major factors for enhancing their maximum utilization and exploitation of university library resources.

\section{Acknowledgment}

The author would like to thank all distance learning students who willingly participating in this study. Without them this research would not have been possible. I also wish to thank members of staff in the Library who helped me to distribute and retrieve the questionnaires.

\section{References}

[1] Adedibu, L. O. (2008). Catalogue use by science students in the University of Ilorin, Ilorin, Nigeria. Libri, 58(1), 58-62. Retrieved from:

https://www.degruyter.com/view/j/libr.2008.58.issue-

1/libr.2008.006/libr.2008.006.xml. Accessed 29 April 2017

[2] Adenike, O \& Akin, O. T. (2014). Online Public Access Catalogue

[OPAC] in Nigerian libraries: a case study of the Kenneth Dike Library and

University of Lagos Library. Ozean Journal of Social Sciences 6(3).

https://pdfs.semanticscholar.org/9f5c/199621c34bf7299a0715d81017783daf2

c6a.pdf. Accessed 29 April 2017

[3] Adigun, G. O, Salvador-Olayokun, M. Y \& Abdulazeez, O. B. (2011). An Assessment of Online Public Access Catalogue (OPAC) Utilization in Two Selected University Libraries in Lagos State, Nigeria. The Information

Manager 11 (1\&2)2011 p.85. Retrieved from

http://www.ajol.info/index.php/tim/article/view/83645/73672. Accessed 21 April 2017

[4] Ansari, M.A. \& Amita. Awareness and use of OPAC in five Delhi libraries. The Electronic Library, 2008, 26(1), 111-29.

https://doi.org/10.1108/EL-07-2012-0093.

Accessed 30 April 2017

[5] Arshad, A., \& Shafique, F. (2014). What do users prefer, card catalogue or OPAC? A study of Punjab University Library. The Electronic Library, 32(3), 286-295. Retrieved from:

http://www.emeraldinsight.com/doi/full/10.1108/EL-07-2012-0093. Accessed 30 April 2017

[6] Bamidele, I.A. et al. (2014) "Faculty Members Awareness and Use of Online Public Access Catalog (OPAC) Services at Babcock University, Nigeria: A Study", Information and Knowledge Management, Vol.4, No.11, pp. 29- 37.

http://digitalcommons.unl.edu/cgi/viewcontent.cgi?article=4193\&context=lib philprac. Accessed 21 April 2017

[7] Butterfield, K. (2003), "Online public access catalogues", in Drake, M.A. (Ed.), Encyclopedia of Library and Information Science, 2nd ed., Marcel Dekker, New York, NY. [Google Scholar] Accessed 2 May 2017

[8] Davis, F. D. (1989). Perceived usefulness, perceived ease of use, and user acceptance of information technology. MIS Quarterly, 13(3), 319-339. https://pdfs.semanticscholar.org/3969/e582e68e418a2b79c604cd35d5d81de9b 35d.pdf. Accessed 27 March 2017

[9] Doty, P. (2002). Online Public Access Catalogs (OPACs). Available at: https://www.ischool.utexas.edu/ 138613dw/website_spring.../opacs.html. Accessed 29 April 2017

[10] Ebiwolate, P.B. (2010). Nigeria Public Library Service to Rural Areas: Libraries in Niger Delta States" (Library Philosophy and Practice (e-journal)

Paper 365. Retrieved on 16th July, 2016 from http://digitalcommons.unl.edu/libphilprac/365

[11] Fabunmi, O. M. \& Asubiojo, B. O. (2013). "Awareness and Use of Online Public Access Catalogue by Students of Obafemi Awolowo University, Ile-Ife, Nigeria." Library Philosophy and Practice. Paper 922. http://digitalcommons.unl.edu/libphilprac/922. Accessed 29 August 2017

[12] Fati OI, Adetimirin A. (2015). OPAC Awareness as a factor affecting OPAC use by Undergraduates in two Nigerian libraries", Inter. J. Acad. Lib. Info. Sci. Vol 3, No. 3, pp 72-80.

[13] Gohain, A. \& Saikia, M. (2013). "Use and Users Satisfaction on Online Public Access Catalogue (OPAC) Services among B.Tech. Students of School of Engineering in Tezpur University: a survey. Library Philosophy and Practice (e-journal). Paper 990. Retrieved from $\underline{\text { http://digitalcommons.unl.edu/libphilprac/990 }}$

Accessed 29 August 2017

[14] Kumar, S. (2012). The impact of demographic characteristics of users on patterns of usage on search engines and OPAC. Library Review. Vol. 61 No. 3, pp. 172-18.

http://www.emeraldinsight.com/doi/full/10.1108/00242531211259300

Accessed 9 August 2017

[15] Kumar, S. \& Vohra, R. (2011). Online Public Access Catalogue Usage at Panjab University Library, Chandigarh. Journal of Library \& Information Technology, 31(4): 302-310. https://search.proquest.com/openview/fb0cfdbe5a721efb3dc0e00f27a72de3/1 ?pq-origsite $=$ gscholar\&cbl=2028807. Accessed 29 April 2017

[16] Kumar, S. \& Vohra, R. (2013) "User perception and use of OPAC: a comparison of three universities in the Punjab region of India", The Electronic Library, Vol. 31 Iss: 1, pp.36-54.

http://www.emeraldinsight.com/doi/full/10.1108/02640471311299128. Accessed 29 March 2017

[17] Markey, K. (1985) Subject searching experiences and needs of online catalogue users: implications for library classification. Library Resources and Technical Services, 29, 35-51. Google Scholar. Accessed 2 May 2017 [18] Msagati, N. (2014). Awareness and use of scholarly electronic journals by members of academic staff: A Case Study of Dar es Salaam University College of Education (DUCE)" (2014). Library Philosophy and Practice (ejournal). Paper 1124

[19] Mulla, K. R. \& Chandrashekara, M. 2009.Access of Web-OPAC in Engineering College Libraries in Karnataka: A survey. SRELS Journal of Information Management, 46(3):321-32. Available online http://www.academicjournals.org/ijlis. Accessed 29 April 2017 [20] Moore, S. (2006). What are the factors that influence the public's use of OPACS? A study submitted in partial fulfillment of the requirements for the degree of Master of Arts in Librarianship the University of Sheffield. http://dagda.shef.ac.uk/dispub/dissertations/2005-

06/External/Moore Sarah MALib.pdf. Accessed 12 March 2017 [21] Morupisi, L. \& Mooko, N.P. (2006). Using the online public access catalogue at the University of Botswana. Information Development, 22(3), 197-204. http://journals.sagepub.com/doi/abs/10.1177/0266666906069196. Accessed 31 April 2017

[22] Nwalo, K. I. N. (2000). Collaboration in the provision and utilization of IT facilities for library and information science education in Nigeria. In Papers Presented at the 10th Biennial Conference of NALISE: 42-49.

http://educ.ui.edu.ng/Nwalo-Publications. Accessed 12 April 2017

[23] Onuoha, Uloma Doris, Umahi, Felicia O., Bamidele, Itunu (2013) Use and satisfaction with online public access catalogue in selected university libraries in Ogun State, Nigeria Information and Knowledge Management, Vol 3, No 11 (2013).

http://iiste.org/Journals/index.php/IKM/article/viewFile/8795/8885. Accessed 20 April 2017 
[24] Popp, M. P. (2012).OPAC. Accessed from:

https://books.google.co.zm/books?isbn=1466618221. Accessed 20 April 2017

[25] Ruzegea, M. (2012). "The Usability of OPAC Interface Features: The

Perspective of Postgraduate Students at International Islamic University

Malaysia (IIUM)" Library Philosophy and Practice (e-journal). Paper 691.

Accessed 10 April 2017 from http://digitalcommons.unl.edu/libphilprac/691

[26] Shaheen, M., Mumtaz, A. A., Tamara S. E. (2001) "User perceptions of

library effectiveness in Malaysian agricultural libraries", Library Review, Vol.

50 Iss: 4 , pp. $176-186$.

https://www.researchgate.net/publication/235267915_User_perceptions_of_li brary_effectiveness_in_Malaysian_agricultural_libraries. Accessed 2 April 2017

[27] University of Zambia. (2016). The University of Zambia Calendar, 2014 - 2016. Lusaka. UNZA Press.

https://www.unza.zm/international/media/files/course catalogue.pdf.

Accessed 20 March 2017

[28] Yusuf, K. F. (2012). Utilization of online public access catalogue (OPAC) at the Lagos State Polytechnic Library in Nigeria. Journal of Research in Education and Society, 3(3), 19-27. Retrieved from http://www.icidr.org/doc/ICIDRPDFcontents/journal of research in education and society/JRES_VOL3_NO3_DEC2012/Utilization of Online Public Access Catalogue.pdf. Accessed 20 March 2017 